\begin{tabular}{|c|c|}
\hline & $\begin{array}{l}\text { International Journal of Trend in Scientific } \\
\text { Research and Development (IJTSRD) }\end{array}$ \\
\hline 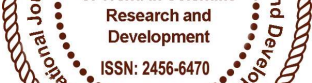 & International Open Access Journal \\
\hline 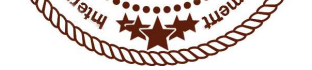 & ISSN No: 2456 - 6470 | www.ijtsrd.com | Volume - 2 | Issue - 2 \\
\hline
\end{tabular}

\title{
Modern Poetic Trends of Odisha versus the Neoteric Strives of Guruprasad
}

\author{
Santosh Kumar Nayak \\ Assistant Professor and Head, (O.E.S.-I) \\ P.G. Department of Odia Language and Literature \\ Government College, Dayananda Vihar, Koraput, \\ Odisha, India
}

\author{
Dr. Akshay Kumar Panigrahi \\ Lecturer, Department of Odia, B.P. (Degree) College, \\ Santaragadia, Balasore, Odisha, India
}

\section{ABSTRACT}

This paper tries to bring out the literary trends of Odia literature from nineteenth century to the last part of twentieth century. With reference to the long literary passage of some 175 years attempts have been made to introduce Guruprasad Mohanty and churn out the specialty by the by of his poetry. How the passage runs, with what level of frequency and with what newness- all these things are discussed here in this article. What was the need of the modern literature and why it is so- everything in this regard has been discussed along with various proofs. The real and underneath reasons of complexity of this postindependence literature or the attitude and nature of this literature (especially poetry) are brought out here. Especially, here efforts have been taken to differentiate between the pre-independence and postindependence literature. Again, in one of the sections, there is a sketch of influences, inspirations and impacts of T.S. Eliot, his life, literature, philosophy, style and personal doctrines. Further, how he has influences Guruprasad Mohanty has also been discussed with ample examples. Overall an assessment has been made on the originality of Guruprasad's literature as well of the attempts of some other contemporary poets of this period.

Keywords: Modernism, Post-modernism, PostColonial, Deconstruction, Glocal

\section{Introduction}

Any form of literature, any kind of writer of any time, any age or space is really dependant and associated with the society, its culture, tradition, economic condition, collective psychology and political background. A writer is a responsible citizen of the state who shows the probable future, inner truth of present time and churns the crux out from the past through his close investigation, analysis, scrutiny and anatomization. S/he perceives very close and finds the delicate truths of life and society. Guruprasad and Eliot, both were so serious, card-carrying and deepdyed unwavering authors of twentieth century. They are very faithful, staunch, and steadfast writers in the eyes of critics of any hour. All these have been proved by themselves by through their own literary works. Eliot's 'Four Quartets', 'The Waste Land' and some other significant works are the evidence of the same thing. Similarly, all the poems of Samudra Snaana and also of the compilation Aashcharjya Abhisaara are sufficiently enough to prove this statement true. Both Eliot and Guruprasad believed in similar ideologies. Hence, they have challenged the so called trend of literature and have literally brought exemplary revolution.

Literary Trends of Odisha: A Brief Investigation

The term 'Aadhunika' is not at all same to that of the English term 'Modern'. These two are so different 
from each other. But we have accepted these two terms as one with respect to the meaning. The term 'modern age' in Odia literature started in the latter part of nineteenth century. This is the time where new attitude came in the cerebral corner of individual, society and hour. Some new kinds of consciousness developed in this phase. This newness gave a serious challenge to the traditional ways of living. And finally a kind of rejection was thereto the old, the medieval and the ancient, literature, patterns, and forms and features in the common mind of the hour. Racial changes were witnessed in between. Those are- (i) printing press foundation in Odisha with the help and impact of the missionaries (ii) a new kind of socioreligious literature begun, (iii) the spread of education was encountered especially the spread of English education, (iv) the reflection of western thoughts nd western pattern in the literature and the society of Odisha, (v) people became more alert and more conscious about the news, mass communication and other parts of the world etcetera, (vi) some socioreligious reformations were there in the life and society of Odisha by the influences of the missionaries as well as the Bramho Samaj, the Aarya Samaj, the Theosophical Society and some other groups like these. Mind became free from the shackles of conservatism towards openness and freedom. Development of prose in different genres and forms was encountered in this time and it was developed much more the time being. This in fact, brought the modernism in Odia literature. While introducing the modern Odia literature in the survey cum selected anthology named 'Modern Indian Literature: An Anthology' (edited by K.M. George), says Professor J.M. Mohanty,

"The creation of a new literature, hitherto unknown, in different genres, responding to a change of taste and sensibility which opened new dimensions of expression." (297)

The passage has been elongated till the contemporary period from Bhima Bhoi and Radhanath Ray. Without ant full stop we see the trend continuing till 1910-11 and after that we see further continuity till 1920 with a spirit of patriotism and nationalism. Then we encounter the flow of Odia literature with some colons and comma and semicolons till 1935-36. But after this we see a prominent full stop in the trend and find a new flavour, colour and taste in the trend. This enlisted till the independence, i.e. 1947. In fact, till 1946-47 we encounter the red literature with a clear cut commitment with utmost reverence to Karl Marx and Mao-Tse-Tung etcetera. A kind of revolutionary communist literature was there. We can easily find the difference of Guruprasad's pen and ink from those literatures. However, Guruprasad has also written some Sabuja poetry (Green Poetry) in his early phase.

\section{Modernity until the Sabujities versus Guruprasad}

Modern Odia literature though initiated from the verses of Bhima Bhoi, the Mahima saint of Odisha still it took its pace more seriously in the pen of Radhanath Ray. We map the modern Odia literature in different phases, i.e. from 1803 to 1910 (Phase-I), 1911 to 1920 (Phase-II), 1921 to 1935 (Phase-III), 1935 to 1947 (Phase-IV), 1949 to 1960/70/80 (PhaseV), 1980 to 2000 (Phase-VI) and 2000 and onwards (Phase-VII). In this measurement we see literature from Phase-I to Phase-IV through the spectacles of Pre-Independence Culture and practice while from phase-V to phase-VII we encounter literature with a mood and motif of post-independence philosophy; a kind of post-independence mania. Guruprasad comes in the beginning of phase- $\mathrm{V}$ and twinkle till the end of phase-VI. Historically we encounter the distinctive voices of Radhanath Ray, Gopabandhu Das, Kalindi Charan Panigrahi, Sachhidananda Routray and then Guruprasad Mohanty through the ages and phases discussed earlier. Even till today nobody has that much been distinctive as the aforesaid figures. Thus Guruprasad is not only a challenging fellow but also a master piece of Modern Odia poetry. Many of the critics don't accept separately any sui generic voice after/Radhanath Ray even until 1920. All the nationalistic spirit of the Satyabaadi age had already been Radhanath Ray. Even in form, none has crossed Radhanath in poetry. The Satyabaadi School though was aggressively nationalistic and was blind in one word (Nationalism), in one direction, in one theme but it is quite clear that all these nationalistic and patriotic things were there in the poetry of Radhanath Ray. Soon after they all (Gopabandhu Das, Nilakantha Das, Godabarish Mishra, Harihar Acharya, Krupasindhu Mishra) plunged into the sacred fire of freedom movement the literary pace of Odia literature ceased in one type. "The cyclonic blast of Gandhian movement, however, broke that tradition, a break that the nation had not known even during four centuries of a dismembered existence,"(232) says Mansinha. He further adds to this- "And the break, apart from the vacuum created by the disappearance of the Satyavadi School, was heightened and intensified by the rise of a group of young writers whose roots were not only nowhere in the Oriya speaking lands, but whose muse derived its inspiration direct from Bengal and Bengali 
language, against the influence of which the Satyavadi School as a group and Pandit Nilakantha Das in particular had waged an uncompromising battle, in all that they did, said and wrote." (2012: 232) There we encounter some young poets who had no give and take with the freedom movement or any reality of the state. They were just the lover of the light sides of life and the haters of the other side. They had no experience of reality or about the bitter and naked truths of life. They were writing the juvenile love poems drench in exclusive romance and physical beauty. By the way, we found some newness in this phase, though were not so strong and committed ones. They were escapists basically. They wanted to be escaped from the thread of reality. Even, they preferred to be in an imaginative world among the angels and to live and dance and romance and to wander within a fictitious earth. Annada Shankar Ray, Baikuntha Nath Pattnaik, Kalindi Charan Panigrahi, Sharat Chandra Mukharji and Harihar Mahapatra were the five friends of the age. Some other friends and authors were there also who accompanied with these five friends in many literary works in this motion. For example, they had written a novel named 'Baasanti' with the help of nine writers who wrote a few chapters each and sketched some of the plots and sub-plots of the novel together to create a joint novel like the 'Chatushkon' and 'Baaroyaaree' novels of Bengali language. A number of poems were written with the tidal influence of Tagore both in the cases of theme and style. In fact, the entire age was affected by Tagore all over India in all the literatures of different languages. The leader of this group was Mr. Annada Shankar Ray though he has written a few poems and essays. His 'Sabuja Akshyara' compilation is the master piece which may be cited here. The poems of Annada were not only of different taste but also they were the representatives of the age, the trend; the entire group or the Sabuja (Green) Literature. The poems are: 1. Pralaya Preranaa, 2. Srujana Swpna, 3. Maanasee o Mu, 4. Jaubana Thare Gale Aau Aasenaa, 5. Paree Mahala, 6. Pranayee, 7. Kamala Bilaasee Ra Bidaaya, 8. Saagara Prati, 9. Udbhinna Jaubana, 10. E Jeebana Delaa Mote Kie, 11. Kaunasi Priyaa Prati Kaunasi Priya, and 12. Sabitaa. Similarly, there are some nineteen essays and criticisms of different forms and tastes. They are: 1 . Saahityikaa, 2. Basanta Gaathaa, 3. Padmapaakhudaa, 4. Samara O Saahitya, 5. Bhaaratara Chitra Shilpa, 6. Kholaa Chithi (Naareera Mukti), 7. Kholaa Chithi (Bibaahara Aadarsha), 8. Kholaa Chithi (Jaubanara Aabhaasa),
9. Kholaa Chithi (Bhabishyata Darshana), 10. Khela Ghara, 11. Nara Chakshyu re Naari, 12. Ellen Key, 13. Samaaja Sanskaarara Ka, Kha, 14. Barnard Shaw nka Matabaada, 15. Bhabishyata Shaashana Tantra ra Bhitti, 16. Shantiniketan, 17. Jugabeenaa, 18. Saahitya Smruti, and 19. Parichaya Patra. Under the intense influence of Rabindranath Tagore's 'Sabuja Patra' the newly sprung group of poets of Odisha started this new trend of literature with the new taste and new flavour and thought. Regarding the age of Sabuja says Chitta Ranjan Das in his book ' $A$ Glimpse into Oriya Literature'-

"The Sabuja were an intentional group of writers who started writing with a and with mainly a blasting enthusiasm as their capital. The group got its inspiration from the movement in Bengali literature. Brought in by Pramatha Chadhury's 'Sabuja Patra' and borrowed very much from its stylistic themes." (218)

Mainly, Annada Shankar Ray, Kalindi Charan Panigrahi and Baikuntha Nath Pattnaik were the active members of the group who had some significant contributions with regard to the central theme of the group. They had been moved by the contemporary Bengali literature. Annada Shankar was the leader of the group though he had written only fourteen numbers of poems in gross in Odia language. "This new group, under the leadership of young Annada Shankar Ray, who was already known all over the state as a brilliant student, consisted of halfa-dozen of his undergraduate friends in the Ravenshaw college, the premier educational institution of Orissa. The group is now generally known as the Sabuja or the 'Green' and the works it produced are collectively described as Sabuja Sahitya or the Literature of the Greens," (2012: 232-33) says Dr. Mansinha. Further, about the ideology when the race took its pace, C.R. Das says-

"According to him, the Sabuja group had humanism as its principal inspiration and article of faith."(218)

He indulged himself into the waves of Bengali literature soon after he gets success for his debut in Bengali literature. Further Das adds, "And after him most probably the group in Orissa also got split to mean individual writers only. Kalindi is more known in Oriya literature as a writer in prose, and though he did venture into some poetry in his early years, the 
mature poet in him came out only at a later period, about a decade after the Sabuja Movement had its day."(219) In this regard, B.C. Acharya says, "The neighbouring poet Rabindranath was the principal source of the inspiration of the Sabuja school. [...] in the contemporary period the rise of the Chhayaabaadi group occurred with the inspiration of Rabindranath's mystic philosophy. The mystic imagination and an intense romantic introspection deeply and widely moved this newly sprung group of poets." (2001: 200) Dr. Mayadhar Mansinha, in chapter XVII of his book 'A History of Oriya Literature', says- "The group's very name, Sabuja, was borrowed from the Sabujapatra of Pramatha Chaudhuri, the famous Bengali prose stylist, and friend and associate of Tagore. Sabuja or Green, as used again and again by Tagore himself, in his poetry, was a symbol for rebellious youth. But, with Rabindranath and Pramatha Chaudhuri, the word was almost a credo, a philosophy of life. It came to them late in life, in the maturity of their experience and studies, as a sort of shock-tactic to shake off the mental lethargy of their countrymen, enslaved more by their own social and religious customs than by alien rule. The word Sabuja was for them a call to the youth of the country, to revolt against all that was lifeless, senseless, joyless and ugly in our society, to bring a new zest into our intellectual and spiritual life, a new appreciation of the physical beauty of the earth." (233) Another famous figure of the trend is Dr. Mayadhar Mansingha. He is known for his romantic poems as poet of love and life, spring and blossoms. But he is an individualist in the trend of Odia literature.

"He seems to have retaliated by becoming more romantic and more of an escapist himself. His oft-mentioned poem about boating in moonlight in the Mahanadi is escapism out and out though the poet has very much tried to imitate Keats's ode on the nightingale for a style and an appeal, what he offers is basically nostalgia, obstinate and yet not honest. Manasingha has thus throughout his entire career as a writer remained almost ludicrously torn between the old and the new, between the romantic and the modern. The volume of his writing is enormous, undoubtedly suggesting that real love of his life was to write and to express himself." (223)

Mansingha is really a versatile writer. His poetry ranges from the romantic pillars to the realistic ones, again he has written poems on spiritual themes as well as on death. He has written poems of different styles but with music. A kind of music runs beneath the lines of the poetry of Manasingha. He has written some poetry which are really interesting as they range from progressive theory to spiritual ones in a single attempt. Says Chittaranjan-

"His poetical works can be studied phase by phase thus clearly marking the various stages of his commitment to his writings. The range is formidably vast, from his direct love poems full of the fervor that comes out of the languor for the beauty in flesh to musing on Gandhi and the Cross on which Jesus had dies. The romantic runs all through as the common coagulant. The most beautiful and lovable thing about poet Manasingha is a heart that reveals at everything grand and great and is moved at the very first instant of such an encounter." (223)

Mansingha was really a remarkable poet of the time. The specialty of Dr. Mansingha is his uniqueness. He was free from the so called trend and passage of literature.

"It is said previously that Mansingha was an individual poet of the time. He was with the trend of literature of that time and was not at the same time. He added special flavour and taste to his poems and established a new tradition. He was romantic but not like the Sabuja. He loved and wanted to enjoy the thrill but sticking to this earth, not leaving it. He never did think to go beyond the world of dream. He was a true poet of this soil, dust, of this flower, spring, and sky and of all seven colours. He is a poet of mankind, his wills and existence." (Nayak: 2017, 26)

By the way, after freedom Mansingha has been more realistic. This is the social implication. The dream and its failure forced the literature to be more serious and away from the fictitious world and to be more vigilant and serious. Mansingha became vigilant for this only in those days. We see similar things in the literature of Gopinath Mohanty. He had many aspects in his pen regarding the great heritage of Socio-cultural heritage of Odisha. He has thrown these things in the lap of his literature very directly and very freely. Says S.K. Nayak in this regard-

"Mansingha has a number of poems embedded in the synthetic culture of Odisha. We find the 
art, architecture, socio-cultural life, the glorious past of Odradesha, Kalinga, Utkalinga, Utkal, Odisha and the harmonious whole within it. Mansingha, in fact deeply loved his land Odisha, to its people, hills, rivers and rivulets, its land, water, air and natural beauty and even to the each and every dust of it. The poet was so very straight forward and nostalgic and a patriot to his mother and mother land." (27)

Mansingha has his significant and unique contribution to the trend of Odia literature but these are with particular style and approach which is quite different from that of Guruprasad. Guruprasad has his deals with the cultural aspects of Odisha but those deals are really experimental. He has applied those in the guise of myth, symbol, image and other poetic devices. Some time Mansingha has made his deals with Arnold and some other poets of seriousness of that height and of that tendency whereas Guruprasad has made those with very much clarity and dexterous perfection. Says Nayak, about Mansingha's works that-

"No doubt, the poet is very romantic his beloved girlfriend and even to the beloved mother land, but he is at the same time conscious about the present catastrophe of the values and ethics and war oriented and quarrelsome attitude of the so call time and people just as the poet Mathew Arnold, who is equally philosophical and serious about the Parish and English state and people and even of the world in his notable poem Dover Beach. Mansingha has a number of talents, beauty and significance embedded in his poetry. His manifold talents also imply the intense of his love and purity of his head, heart and humanity. Yes, of course, he was a perfect human being, in a true sense." (Nayak: 2017, 27)

Not to be in the general motion and creating a new chapter of own is not at all a small work. Sometime he has been spiritual, sometime metaphysical, sometime he has been mystic and some other time he has been so much romantic. Sometime he has been progressive by nature and some other time he has been the worshiper of the mundane beauty of nature and organisms as well as of human body. Therefore he has been a new chapter with hope and noble aspirations in Odia literature; an independent one. "Mansingha has rightly opened a new chapter in Odia language and literature with his noble writings. He speaks the naked, earthly and the chesty love of man and woman, which is hardly spoken by any other poet of Odia literature or any other Indian literature. He also speaks or laments about the human misery and the downfall of the whole humanity just as the English poet, P.B. Shelley, who is very serious about the uplift of mankind and the human spirit as well in his ground breaking poem "To a Skylark". It may be noted that Dr. Mansingha was moved by the British poet P.B. Shelley. Shelley's notable poems Ode to the West Wind's optimistic philosophy is seen in the attitude of Mansingha. Mansingha has personified many things such as the clouds and other things as Shelley, but here it must be said that this poet has not reached that height of spiritual divinity at all spheres as Shelley does. Mansingha was an uncompromising rebel as P.B. Shelley, the greatest romantic poets of early nineteenth century. He continued his struggle for the cause of individual liberty, social justice and peace and the advancement of the mankind and for the uplift of the language, literature, race and community just as Shelley. He wished to bring social reforms by his inspiring and courageous works of literature. $\mathrm{He}$ dreamt of an ideal society in which there should be no slavery and no exploitation just as P.B. Shelly. In the poem Nidrita Bhagabana (The sleeping God) the poet laments for human sorrows and sufferings and he thinks of the great purity and height of the human soul as Shelly thinks a couple of steps ahead in the poem 'To a Skylark'. He has addressed there in the poem to a skylark (a little bird) that soars up at a great height and sings so sweetly that the world is enchanted and bewitched by its sweetness. The skylark is not seen as the soul is. Mansingha has trades with this matter too. But it must be said that Mansingha has much more deals with the reality here as compared to the poet Shelley and less deals with the spirituality as compared to Shelley. Yes, the poem has no lesser depth in both the aspects." (Nayak: 2017, 27-28) Few other distinctive voices of the time are Radhamohan Gadnaik and Godabarish Mahapatra and some other persons. They have simply written the central theme of this soil and air and water.

Immediately after this trend, the pace and face of Odia literature changed drastically. A red colour came into the vessels of literature in Odisha. B.C. Acharya says, "Due to the rise of Marxism and Communist philosophy this Sabuja trend got declined by 1935." (201) Even, the new trend did not hesitate to criticize the tone and the theme of the Sabuja age. Sachhi 
Routray has widely criticised the Sabuja poets and even other poets of the same tone. Chittaranja Das says in this regard-

"The literary scene in Orissa as Independence came acquaints us with the following poets and writers who were very much known as prominent ones. In poetry it was the day of Sachhi Rouroy (b. 1913) who has many worthy examples to his credit in prose writing. His poems of those youthful years have been compiled into collections like Patheya, Pallishree, Abhijana, Baji Rout and Pandulipi. These poems were written in a style and a tone that seemed to be Routroy's very own and more than anything else indicated the great love that Routroy had for life that might be. He sang of freedom, of justice, and of a society where every man can live with dignity and hope Baji Rout made Routroy especially endeared to readers in Orissa and outside in India. [...] This was the phase of Sachi Routroy, the revolutionary. The other Routroy that was yet to be hatched out later under another sky was nowhere to be sensed in these early creations of his." (1982: 236-37)

Another significant poet of this time is Ananta Patnaik. He has written a number of poems in this taste and tone. Besides his there were some other writers namely, Manamohan Mishra, Raghunath Das (Jataayu), Rajanikanta Das, Banchhanidhi Das, Kunja Behari Dash, Krishna Chandra Tripathy and some others too who have some significant contribution to this literature of various tones and tastes. Manamohan, Raghunath, Ananta, and some other were engaged specially in the progressive thought and the red motion of literature. They have written a number of poems in this light and in this taste. But Kunja Behari and Krushna Chandra have preferred to write something new and different from the main motion of the time. One of the best critics of Odia literature, Chittaranjan Das says- "Tripathi is a humanist, a lover of man and nature and believes in the good in man. He sings of a new society where life fulfils itself by seeking for more life." (1982: 237) He has written a number of lyrics, odes, sonnets and some patriotic poems. He is a great philanthropic poet who has written a bunch of poems of beatitude. Interestingly, we should note the progress of Odia literature. How dramatically we reach at the age of Guruprasad. We can easily estimate the frequency and density of intellectuality in post-sixties poetry of Odia literature, especially which originated from Routray and Mohanty's (Guruprasad Mohanty) attempts. Kunja Behari Dash has used his brain in order to make his poem beautiful along with the heart of a poet for its delicateness. Of course Sachhi Routray has started the motion and the pace of the this new literature but the perfect shape with a delicate touch has only been given by a single person in the developing trend of Odia literature and this credit must go directly to the account of Guruprasad Mohanty. Mohanty has started that with the combined effort of himself with his bosomed friend Bhanuji Rao. The compilation is 'Nutan Kabita'(1955). From here the trend of New Poetry started in Odia poetry.

Professor J.M. Mohanty has divided the trends into groups and he says that there are four groups who came before independence from the beginning of the modern Odia literature. K.M. George has edited a book on this entitled 'Modern Indian Literature: An Anthology'. In the volume one of this book only the surveys of poems of modern Indian languages and literatures have been placed along with some selected translations and transliterations of a few poems. Here Mohanty says-

"Till independence, the most important form cultivated by Oriya writers was poetry. Radhanath was the presiding spirit; subsequent poets largely took inspiration from him and elaborated, through at times with significant departures on the main directions set by him. The essential inspiration was, in a way, nineteenth century English romantic poetry, and poets such as Wordsworth, Shelley, Keats, Byron and Tennyson could be variously seen as animating the verse of this period. It would be convenient to consider the important poets subsequent to Radhanath in four groups, seen more or less chronologically." (1992: 303)

In the very first group he places Radhnath Ray, Gangadhar Meher, Nandakishore Bal, and Madhusudan Rao. Similarly in the second group we see Gopabandhu Das, Nilakantha Das, and Godavarish Mishra. In the third group we encounter some independent poets such Padmacharan Patnaik and Laxmikanta Mohapatra. And in the fourth one we find Kalindi Charan Panigrahi, Baikuntha Nath Patnaik, Mayadhar Mansingha and Radhamohan Gadnayak. Further he (Mohanty) adds- 
"For about seventy years, as has been pointed out, beginning from the time of Radhanath till Independence, or a little after, Oriya poetry developed more or less along the main lines mapped by Radhanath himself and his closest friend Madhusudan, though there have been several variations and changes depending upon the times and tastes. In the thirties and forties particularly the Oriya literary scene was full of activity. There were a number of influences, from within and outside the country, such as the freedom struggle on the one hand, and the Marxist ideals of contemporary Europe on the other. the writers took pleasure in organizing themselves either in movements (Sabuja Andolana) or in associations (Nabajuga Sahitya Sansad), [...]" (1992: 306-07)

Ananta Patnaik sung the fire belching inaugural song of the Sansad (Nabajuga Saahitya Sansad). It was very powerful and influential at that time. It took so many changes in the cerebral corner of the time, people and society. A few lines of the song may be quoted here right below:

"Awake, the youth of the new age Awake, and break your fetters Pour your heart's blood And spread fire in million lives Break all bonds Dry all tears

Destroy all castes Unite all countries Blow the conch of all humanity Let the sorrows go And arise, arise, awake, awake."

(Translated by J.M. Mohanty)

We can remember the powerful lines of 'Konarka', a poem written by Sachhidananda Routray in response to the 'Konarka' poem of Mansingha. He says there-

"You have seen the beauty of art on chest of the black stones,

But I have seen there the heaps of broken hearts of the numberless skeletons."

Further the poet Routray says that he has seen the scene with the eyes of a labourer, a daily wager, not as a poet, not as a philosopher of anybody else. This shows the realistic orientation of the poetry of Routray and of course of the time. We can never fail to remember the lines of 'Baji Rout' by Routray that inanimously criticize all the green poets; the poets of Sabuja consciousness. The few lines and expressions are like this- "Hey, you escapist, where are you going to... leaving and cutting the glands and the bonds of this Earth?" or "O poet, the lotus loving poet, tell me whether this news has reached your ears, in your kingdom?" This is the taste of progressive literature of Odisha over all. And from this we can easily mark the distance and difference of taste and texture of Guruprasad's literature (poetry).

\section{Post-Independence Odia Poetic Trend versus Guruprasad}

After a couple of World Wars, fight for freedom and such other things of the first half of the $20^{\text {th }}$ century we encounter some radical changes in Indian as well as Odishan socio-economic, socio-psychological socio-cultural and socio-political climate. The theme and the context of literary consciousness embodied the lethal, malicious and vitriolic consequences of the World War and the downfall of dream and desire of independence. The price of human smile and dream found null and void. Independence went in vain. This hopelessness became the main theme of the literature of this period. Hopelessness, cataclysm of ethics and spirituality and death in life was the centre of the theme of post-independence poetry in Odisha. A rigorous socio-cultural fusion was there among the Odishan and British culture and practice etcetera. It could be better named as European impact on the East. The Industrial revolution that had been started in Europe since 300 years ago had its impact on Indian society and practices. After independence, in India, the industrialization started and took its pace well. Just after this, we noticed the revolutionary change in the social thought process in India and Odisha just like the Post-Industrial cognitive change in Europe. Life became industrialized and city-centric. The real and pure charm and beauty of life lost by the by. The pain of civilization came as a major theme of literature. Basically, the poets, who were connected to the western literatures, brought this idea and recognized the same state of mind in this soil-air and water quickly and reflected in literature with certain poetic devices like image, symbol, myth, paradox, oxymoron and other techniques. The postindustrialization thought stirred not only the mind of individual but the mind of society thereby. The tendency of imagination and dreaming vanished slowly from the mind of the people and poet. The 
poets became the poets of people and now, people became poets easily as there was a little distance between them. Poetry became closer and closer to the people. Another new thing came here due to many reasons and factors. That is the struggle with the self. This made the people tired and faded. Traditions were of no value and nobody had time, thereafter, to pay attention even to observe the religious doctrines, cultural and spiritual rituals. This is why we started living in a rootless society, where there were no culture, no tradition, no religion and no origin. That was a civilization but a root. For this, poet Guruprasad Mohanty wrote the long poem with the title 'Nirmooli' which was later changed to 'Kaalapurusha'. Hence, this poem has its deal only with the root-less, base-less and aim-less society. Meaninglessness became another major theme of the time. Because, the entire society and the societal doctrines, beliefs and the adoptions were meaningless, vague and just like a chase and restless run after a mirage. Hence, the poets of this period like Sachhidananda Routray, Benudhar Rout, Guruprasad Mohanty, Ramakant Rath, Sitakant Mahapatra, Kamalakant Lenka, Rajendra Kishore Panda, Saubhagya Kumar Mishra, Dipak Mishra, Pratibha Satapathy, Harahar Mishra etcetera started writing poems of this tastes. Especially Ramakant, Kamalakant and Sitakant wrote a number of poems in the theme called meaninglessness. Death became a major part of literature. Because, now the death was ruling after life as before and in life as well, this is much more painful and hazardous for life and its charms. The terms regarding this phenomenon have been coined by professor Dasarathi Das in his book 'Adhunika Kaabya Jgnyaasaa: Chitrakalpa'. This has been termed as "death in life" (Das: 2015, 253) and "life in death" (Das: 2015, 253) in modern poetry. Right from the development of science and technology, Gandhism and Marxism different western thoughts and philosophies were established in the thematic matrix of the post-independence Odia literature. $^{[3]}$ Gandhi had a pivotal role in the independence of India. Hence, post-independence Odia literature reflected this thought in different ways. The practice of non-violence and the path of truth etcetera were of no value. Hence, the failures of the doctrines of Gandhian philosophy were also reflected in the literatures of this time. Ethics died. Humanity, chastity, natural beauty real societal pillars and ambitions doomed. Dr. P.K. Rath defines and divides "the post-independence Odia poetry into three forms from the angle of theme, thought and style. They are: a. Social Consciousness Centric Poetry

b. Individual Thought Centric Poetry

c. Mixed Poetry
i. Communist
ii. Non-communist" (Rath: 1996, 9.2)

We see a larger impact of Bengali literature on Odia literature in many aspects. Poets like Sachhidananda Routray, Raghunath Das (Jataayu), Rajanikanta Das etcetera are the evidence of the same. P.K. Rath says that "before 1950 there was a greater impact of Bengali poetry on Odia poetry but after 1950, we encounter a direct impact of English language and poetry on Odia poetry. For this, he says, Odia poetry was divided into two classes, i.e. social consciousness centric and individual thought centric." (9.2) Further, he has rightly observed the trend and its moves minutely and says, "the 'Individual thought centric poetry' were patronized by some high-rank and higher degree holders and these kind of poetry were very intellectual and often difficult to understand easily by the common readers." (9.2) "Here, we see the different styles of poetry evolved in Odia literature like: poetry of prose style, poetry with new arrangements, deep philosophy based poetry even individual experience based poetry became lively with the intellectual uses of similes, adjectives, metaphors and symbols," (9.2) he adds. Behind poetry there are certain reasons for which it takes its origin. Dr. P.K. Rath further adds his introspective commentary about the configurations of poetry in general as well as the post-independence poetry-

"Intellect, Inspiration, Endeavour and Aptitude (Talent) are the four classic pillars of poetry. But in post-independence period, only 'Intellect' was given importance and often regarded as the main source of poetry." (9.2)

The age of globalization, industrialization and many other things made the world smaller and hence French, English and other literatures came in contact with the Indian and Odishan literatures. Mainly, British literature fused with Odia literature in different forms and dimensions. The orientation of the trend of post fifties poetry is well told in the thesis of Dr. Rath. He says-

"Like the medieval poets, who were engaged in bringing the Sanskrit tradition and imitating the Sanskrit poetry, some poets were thoroughly engaged in imitating the Western modernism, especially the English poetry and 
to establish that in the blood of Odia poetry." (9.2)

Experimentation started thereby with the theme, language, style and many other things. Some poets tried to implant the western gene in Indian and Odishan land, air and water and some eternized those western products.

The individual existence had been doomed and crashed both in the national and international level. Several problems like economical, sociological and some other major problems were there. As a result, existential crisis occurred which became a basic hindrance of each and every sector. The common people were just like a patient etherized on the operation table. We can rightly remember the lines of T.S. Eliot here as he says in 'Love Song of J. Alfred Prufruck':

Let us go then, you and I,

When the evening is spread out against the sky Like a patient etherized upon a table;

Let us go, though certain half-deserted streets The muttering retreats $[\ldots]$

Here, nobody has the courage to fight against any unethical practice. Nobody dares to raise voice against evil things. The existence of human being is in precarious state in the midst of scarcity, problems, poverty, hunger, ignorance and unconsciousness. Everybody is self-centric today. Of course, the causes of the same may be drawn from the above factors. The life is really submerged in the drastic and destitute condition. Dream has been sold at the cost of breath, that is, bread and butter. The flowers of human wills have been wilted in these hostile conditions. There is not even any reaction or protest against pretention. It is a common thing for us today. This was not only a single impact of Eliot on Guruprasad rather there are several instances of impacts on Mohanty's life and literature. He was really an honest follower and in other words a true student of Eliot. Therefore many of the critics designate Guruprasad as the Eliot of Odisha. But it will not be right or justice if we say this only. Because with this we ignore all his other talents which are made absolutely with the atoms and molecules of his own personality, taste and style.

The real concept and form of modernity came in Odisha after the independence of India. The trend took its pace fast just after 1947-50. People in India became the role models of the British people. The way of thinking, the way of behaving and ultimately the way of living changed in due course of sociopolitical and socio-cultural interactions with the British people. Some say that modernism came to Odisha just after 1803 due to the advent of English power, culture and socio-political dogmas and doctrines. But this concept is not true always. Nityananda Satapathy says in his essay entitled 'Development of Modern Oriya Literature (18031977)' (DOMOL) that:

"It should be very much borne in mind, at the outset, that Modern Oriya literature did not flourish all on a sudden with the advent of British Rule in Orissa in the year 1803. Rather it took more than seven decades to make its feeble mark in the middle of the seventies of the last century. The reason can simply be attributed to the slow movement of modern education in Orissa even after sixty years of British Rule.” (Satapathy: 1977, 714)

There were some "notable urban areas like Cuttack, Puri and Balasore" (Satapathy: 1977, 714) where there were a few footprints of modernism. After profound investigation and examination with a kind of research oriented insight, Professor Nityananda Satapathy writes in his essay 'DOMOL' about the post-independence phase of Odia literature very meticulously. How a radical change has been occurred from the early twentieth century and onwards, he narrates very beautifully. How, after the age of Radhanth, the nationalist movement came and there after two opposite trends arouse: the trend of Sabuja and the progressive trend. In his words with reference to the post independence period may be looked as below:

"But the Post-Independence Oriya poetry has undergone many changes and experiments. It has started from a traditional outlook and has crossed all boundaries of tradition. During fifties poets like Sachi Routray and Guruprasad Mahanty have left their romantic ideology and have become more and more realistic. Their poems, though of varying excellence display greater talent and at moments attain height of poetic quality. Mr. Routray seeks to give expression to the urges of mind which almost defy embodiment and yet there are times where thought and feeling have fused in an authentic image of beauty. 
[...] No more he raised his voice for the poor class or the downtrodden. In the sixties and seventies his poetry took a different shape and bade farewell to its striking social purposes. He made more and more experiments in form, verbatim metre (verse lyre) and imagery as a result of which he gradually confined his poetry to himself." (Satapthy: 1977, 714-15)

A number of experiments internally and externally have been performed with the poetry of this period. Death, emptiness, anxiety and time are the major theme of this period. These themes have widened the dimensions and domain of modern Odia poetry. Internal analysis of values and ethics has taken the shape of self-irony and self-consciousness.

"The contemporary trend or the tradition is busy in the collection of wit and irony instead of traditional social or literal values."(Parida: 2013,37)

Radhanath Ray brought a kind of modernity in Oriya literature. He mainly followed Bhanja and truly he was not at all free from his impact.

"Only in case of poetic language and manner, he was following his literary ancestors like Upendra Bhanja. But it is equally true that he has some distinctive specialty in his poetry." (Parida: 2013, 41)

But the Satyabaadee trend or the Sabuja trend could do nothing new in their period. They only followed Radhanath's style and changed the main stream a little. Yes, it is true that the trend after $40 \mathrm{~s}$ and $50 \mathrm{~s}$ suddenly we see a new trend with new flavour and new ideas with new styles. A number of stylistic, formal and thematic experiences have been there in this post-independence period. Professor Nityananda Satapathy has beautifully drawn the sidelights of the socio-literal and political and cultural trend of post independence Odia literature. In his essay 'DOMOL' he says: "Among the contemporary poets Ramakanta Rath and Sitakata Mahapatra stand at the top most position. Shri Rath is the most conscious modern poet who has made many experiments including that in the metrical arrangement of his poetry. His verse, though devoid of lyrical charm, deals with the consciousness of time, death and love. Some of his poems have left an everlasting impression in Oriya literature.[...] He has a fair blending of emotion with intellect in his poetry and deals with eternal pathos of life. But Mr. Mahapatra is very often metaphysical and appears to be more serious in his tone. His 'Astapadi' is considered as a classic creation in Oriya literature which presents a chain of pictures of death, hell and the life after end and beyond. Both Rath and Mahapatra have accepted myths as the archetype of their poetry and both are anxious for rich imagery. Among other modern poets, the names of Jagnnath Das, Deepak Mishra, Saubhagya Mishra, Bramhotri Mohanty, Prativa Satpathy, Harihar Mishra and Kamalakant Lenka of the younger group and names of Dr. J.B. Mohanty, C. Behera, Benudhar Rout, Bhanuji Rao and Bidyut Prava Devi of the elder group are worth mentioning. The elder group appears to be more traditional and rational in its approach whereas the younger group has confined itself more and more and more to a surrealistic attitude behind a thin veneer of nihilistic romanticism. " $(1977,715)$ The postindependence Odia poetry has shown multifarious experiments and colours in it. Several kinds of poetry with reference to form and theme were seen in this period. Some name it as a post-modern phase of Odia literature. He (Satapathy) further adds to this in his final wordings:

"[...] one can say that modern Oriya literature is in a developing stage. It has just completed one hundred years of its existence looking forward with new experiments every decade. It is very difficult to guess as to what would have been its form towards the end of the present century. Although the readers have mixed reaction for it the expansion of higher education will solve the problem and writers will, also, look at the illiterate mass whose percentage is so high in Orissa." $(1977,727)$

Sitakant Mohapatra is the most influential poet and research fellow-critic of the post-independence Odia literature. He has made his significant contribution in the field of language, literature and culture of Odisha. He has written a documentary article on the postindependence trend of Odia literature named 'Connecting Everything to Everything' Landmarks in Post-Independence Oriya Literature (CETELIPIOL)' where he has depicted Guruprasad as a landmark in the same phase or age.

"Discussing the main trends in a literature over a specific period of time is somewhat artificial and may even create confusion in literary developments are better treated in terms of continuities, traditions, linkages; seeds germinating at a point of time and 
flowering at another; the inchoate, new and unfamiliar today becoming the all-too-familiar and cliché-ridden tomorrow. Cataclysms, upheavals are not unknown in the literary developments but they are very rare. Historical periods are more susceptible to sociological analysis of changes in literary tastes rather than trends in the field of creative writing. Thus, when one speaks of landmarks in postindependence literature, the intention is not to treat 1947 as the great divide in the development of Oriya literature, or for that matter of Indian literature. The year of independence is adopted only as a convenient, even though important, point of reference." (Mahapatra:1977, 728)

Entire India has witnessed a great change after the independence. It was a kind of depression phase in the psychological and literary fields. The literature of this time in one hand sprouted its leaves and buds and flowers very well with different varieties and beauty with a connection to the land or the main parental culture at the other hand. Sitakanta Mohapatra has rightly discussed about this. He says- "Our national culture of had suddenly discovered its hidden roots of strength, vitality and complexity. The cataclysmic experiences of martyrdom, the non-violent struggle, Salt Satyagraha, the tyrannies let loose, by an intensive alien raj, the sacrifices of the anonymous millions for the noble ideal of freedom and the holocaust of partition in the wake of independence-all these did, no doubt, find a place in the stories and novels immediately following 1947 and literature was thus intimate with the popular imagination. The folk spirit was right in the centre of the literary concern and literary idiom. The folk, the community was of prime relevance. A literature wedded to immediacy and authenticity of experience seemed possible with its distinctive national flavour. As years flowed by it and imperceptibly divorced from that imagination. I have no doubt someday sociologists of literary evolution in India will analyze the complex turn of events and factors responsible for the development. Literature that is creatively significant has always its roots deep in the soil." $(1977,728-29)$ it is very much true that any literature of any nation is always associated with the root of the culture and civilization. Dasarathi Das, one of the famous critics of Odia literature, has rightly named his D.Litt. thesis 'Chinhaa Maati Achinhaa Aakaasha' (The known soil and the unknown Sky). He has written about the literature of Sitakant Mohapatra here. Therefore we can say in this regard that Mohapatra has rightly therefore remarked that a literature is always attached to its soil; its own culture and tradition and social values. And it is hundred percent true also from the angle of psychology. Sitakanta has rightly remarked in his essay CETELIPIOL in the following few lines. He says- "Our literary categories and literary concerns, with few significant exceptions, unfortunately, followed the patterns of the west and a significant literary revolution which combines the peculiarities of a historical situation and ethos with an aesthetic and literary style all its own became only too rare. This is, however, not to deny the many significant works in Oriya literature particularly in the field of poetry and short story." (1977, 729) With reference to the modern or the post independence poetry Sitakant has given his significant remark. This is true for Odia literature just like the British literature. Odia literature is famous for its poetry as British literature is. But it is true that like French literature we could not have developed our prose section. By the way, we can quote the lines of Mahapatra right here in this regard.

"It is possibly Oriya poetry which has registered the most significant development both in its concerns, thematic complexities and stylistics variations and revolutionary language-use. It has broken grounds, conducted 'raids on the inarticulate' with the worn out and newly fabricated tools of language. It is a colorful and complex mosaic. In 1947, Sachi Rautray's Pandulipi was published. The concern and tone was still romantic and revolt against the established order of things was the major theme. In Pandulipi one could see the search for a new idiom, a language nearer to the spoken word and an element of comparative nonseriousness in its thematic treatment. The poems were thus in the new experimental mode of the post-war years. But in it there were also poems that were superficial in their concern and almost bordered on the rhetoric and the slogan. [...]" $(1977,730)$

In the post-independence Odia literature, especially in the field of poetry the role of Routray is never negligible. In any respect he is not at all 'less' as he has written a great number of poems of a large number of experiments. Those poems are again of various tastes and of different ideologies, political, 
cultural and socio-economic values and doctrines. He has covered the time period from the Sabuja to the Ultra-modern or post-modern age. His pen and brain both are therefore versatile. Therefore with no controversy, all the critics designate Sachhidananda Routray as a trend setter and he truly he is literally second to none. He has written a number of books in Odia and has done a number of experimentations with language, style, theme, culture etcetera in a wider ranger in the beaker and test tubes of his poetry as compared to other contemporary poets. Hence, in this regard the contemporary poet and critic Sitakanta Mahapatra says-

"Routray has no doubt been a tireless experimenter and his experiments in the use of language and diction enriched modern Oriya poetry. These two decades have seen poetry which is tentative in its approach to Reality; which concerns itself with the search for new themes; wants to be in tune with the changed social milieu and yet speaks with meditative, metaphysical tones and couched in a language which, if not identical, is at least very near to the spoken idiom. He has gone on experimenting in many modes and styles and has now almost come full circle." $(1977,730)$

Beside Routray we have some other versatile and vigorous poets in this time. Poets like Binod Chandra Nayak and Gyanindra Verma have written various poems of different tastes right from modernism to post-modernism. One of the poems of Binod Nayak is 'Graama Patha' (The Village Road). It is such a beautiful poem that its original and lovable colour will never be fade away with the rotation or revolution of earth. But his poems of the compilation 'Sareesrupa' (Reptile) are really different in class, colour, and vigour and taste as well. Sitakanta has rightly said in his essay 'CETELIPIOL' that- "Binod Nayak and Gyanindra Verma two other important poets of this period continued with their pre-occupation with outlandish themes and moods. There were liberal references to the Andes, the clover gardens of Zanzibar, the Cossack Girls and so forth in Nayak's poetry though of late he seems to have grown more meditative." (Mahapatra : 1977, 731) But it is very clear that Guruprasad Mohanty is none but Guruprasad Mohanty. Literally he is second to none. He has written a few poems but the poems are very powerful and we can say in this regard that each of them were atom bomb and uniquely significant. His attempts were very generous and revolutionary right from 'Nutana Kabitaa' (New Poetry) to 'Samudra Snaana' (Bay Bath) and even the 'Aasharjya Abhisaara' (1988) and other poems written after it. A new poetry itself means to reject the older ones. He has done this only with his friend Bhanuji Rao in a combo effort. Sitakanta has rightly told in favour of Mohanty-

"A significant voice in Oriya poetry was noticed only in 1955 with the publication of Nutan Kavita, a joint-anthology of poems by Guruprasad Mohanty and Bhanuji Rao. It was immediately seen that here was a kind f poetry which combined lyrical charm with powerful themes and classical qualities. Guruprasad primarily dealt with the decadence of love but it was so different from Routray!" $(1977,731)$

We can better judge Guruprasad and his uniqueness from Routray by looking into the poems written by both the poets with a single name: 'Alaka Saanyaal'. The progonist in the poem no longer remembers the place or event of Videha or Vaarunaavanta. He cannot wait long as before. In the mean while there has been a great change in him, internally and externally. In other words, it is a kind of metamorphosis in the tread of time. Alakaa Saanyaal is an object only meant for sex, the primeval thirst of mankind. Modern time has redefined love with respect to sex. Self-identity, selfexistence and many more things came redefined and renewed. Therefore in several poems like 'Alakaa Saanyaal', 'Gobara Ganesha', 'Harekrushna Das', 'Picnic', 'Aakhira Kapota Mora' (The Doves of my Eyes), Sunaara Jharanaa (Golden Stream/Spring), Kaalapurusha even Champaphula (The Champak Flower), his first poem of the 'Samudra Snaana' (Bay Bath) compilation. In his poems the degraded love for its sex centeredness is held up and the main target is to ridicule and to satire the same. This is the principal theme of his poetry. The hero or the protagonist of his poetry has got nothing in his entire life but falsehood, ostentation, artificiality, snobbery-culture, supercilious behaviour, hypocrisy, impurity, vulgarity, lechery, debauchery and dejection etcetera.

We can directly perceive the psychological sketches of the protagonist of Mohanty's poetry from the narration of an eminent critic and poet Sitakanta Mohapatra below:

"The protagonist is afflicted with his own failures and unfulfilled dreams that bring anguish. He has the emptiness of his own life 
quivering on his palm and seeks fulfillment in packaged pleasures including sex and love. The desiccation in life and the failure in love does not, however, end up in a sense of personalized failure or anguish. Guruprasad gives it a broader dimension as in (1) Herekrushna Das or (2) Picnic where the failure of the protagonist is given a near universal significance. Picnic is a successful poem satirizing the modern life. Its packaged pleasures consists of tea and milk, stove and camera, gramophone and friends and beyond all these stares the emptiness all around. It is only an escape and not a fulfillment. The protagonist is afraid of life and seeks deliverance, aware of his futility and the fact that deliverance cannot be permanent and the City will claim him again. Guru Prasad is an objective poet in whom qualities of detachment and psycho-analysis blend with powerful organizational ability.” (1977, 73132)

The existence and beauty of the life of the protagonist of Mohanty in this phase of poetry has badly been scattered and devastated by isolation, loneliness, fear, sin, unchastity, vulgarity, evil things and vices.. In the midst of this morass his cerebral and psychological balance is maintained not only badly but also pathetically. He says very beautifully that this time has been pregnant with the blending of fear and guilt. The more pathetic issue is that in this situation he has to smile like a marionette or a puppet. This not at all a simple job for a man of this century. This was the trend the poet had to deal with at that time.

"Guruprasad's long poem Kalapurusha has justly been praised by critics and fellowwriters. Kalapurusha has exceedingly charming lyrical passages. More than that, it marked the beginning of a new developmentthe flowering of long poems in modern Oriya poetry. A number of them like Mati $O^{\text {' }}$ Manisha, Bagha Shikar, Solon are powerful poems which delineate the anguished destiny of modern man through a central symbol, myth or archetype. In the editorial of Prajna where Kalapurusha was first published, it was explained that Guruprasad has 'tried to experiment on the limits of the power of Oriya language with certain emotional situations akin to those of 'The Wasteland'. Thus, to an extent, the similarity with The Waste Land is deliberate. Kalapurusha has also far many local associations and deep linkages with Oriya culture, tradition and values to be called a Cuttack edition of Wasteland." (Mahapatra : 1977, 732)

A great hope was there further after these from Guruprasad. He had that much of potency and talent in him. Unlike Bhanuji Rao, one of his close friends, he did not write more poems. He has done limited experiments with his limited number of poetry. The big thing is that he has made a few number of experiments but with a great number of success and the pattern he used in his poetry has made him welldistinctive and identifiable. We can say this is the specialty of a modern and ultra-modern poet like Guruprasad. The rhythm he uses in his poetry is really very interesting and special. It runs beneath the prosaic lines. In fact, in many places he is poetic moreover. He has poetized prose and has converted poetry in to prose as well. "[...], Guruprasad has been rightly acknowledged as the first distinctively modern poet unconcerned with the Radhanath-Madhusudan tradition and the pseudo-revolutionary zeal of the thirties which had its echoes in so much of early Sachi Rautray. It is a pity, Guruprasad has almost ceased to writer over the last ten years. It is difficult to say what development his poetry would have taken if he had continued to write. The co-author of Nutan-Kabita, shri Bhanuji Rao has written a kind of lyrical poetry with delicate nuances of word-rhythms and intimate imageries almost like Chinese scroll paintings. He too has not written much over the last five years." (Mahapatra : 1977, 732)

The literary trend was very zig zag in this period of time. Because life is the soul of society and society is the land with proper germinating factors to germinate the literature. Hence, but the life, but the society, no literature can be alive. Yes that may be dead literature but the spirit of life. The time period was so clumsy and so hazardous that a green literature turned into a kind of pale literature. Ramakanta Rath is another serious poet of this time. "In his poetry one can discover a genuine concern to find a relevance for the modern consciousness overhead by the multiplicity of events and situations."(Mahapatra: 1977, 732) Very beautifully Mahapatra says that -"He (Rath) is a serious poet and portrays the intellectual's frustrations in a world of make-believe. His poetic landscape is a lonely man in a world of broken gestalt and man's desperate bid to discover meaning and significance through the anguish of love and death, [...]" 
(Mahapatra: 1977, 732) Ramakant Rath's poetry has another significant dimension and that is wit and irony. Many of the critics say that Rath is very hard to understand. He is not easy etcetera. This is not the poet's specialty. It is the reflection of the society, people of the time and the life itself. It is the reason why the poets of this period are very hard to understand. Even some 20 to 30 percent of their poetry could not be understood easily. This is because the people of this time are equally clumsy and harder to understand. This could be well accessed from the following lines translated by J. M. Mohanty.

"And I could not follow you because I was lame; That is your freedom,

But when I wake up in the midst of the damp walls And falling roofs

And when all that noise returns,

I, a lame man, would be alone in that brokenness."

Ramakant Rath is a poet of this phase with much obscurity and limitless intellectuality. He was called at time as the absurd and intellectual poet of Odisha with a lot of obscurity and individual image, vision and symbol and thought processes. His very first attempt 'Ketedinara' and the second attempt 'Aneka Kotharee' are the most important compilations for this title of 'obscure poet' in those days. After that he wrote 'Sandigdha Mrugayaa', 'Saptama Rutu' and 'Sachitra Andhaara' etcetera many similar books. But he became too simple and intensive with another approach in his second innings from 'Shreeraadhaa' and his onward expedition. However, critics say him a purely intellectual and some time an obscure poet. Sitakanta Mohapatra says-

"Ramakant's poetic landscape is full of darkness and lonely echoes, the protagonists silent and anxious footfalls and the faint possibility of a return to childhood innocence. His poems show a remarkable capacity to hold on to an experience and explore its many facets in a detached ironical vein. This, perhaps, is the most significant contribution he has made to modern Oriya poetry. His impact on the younger poets of sixties is pronounced deep but by and large they have failed to imbibe his real strength and have only succeeded in imitating his superficial stylizations." (1997: 733)

Ramakant Rath is a true poet who has poetized philosophy in his attempts. His poems look like prose but a delicate poetic sense and sensibility runs within it. The height of imagination he reached in his poetic domain is really unbeatable. What he has thought or what he has sketched in his 'Aneka Kothari' and 'Saptama Rutu' is really second to none. He has given a lively sketch of the world beyond death. It is the poetic power of a true poet. We can also evaluate him as the epitome of poetry or as the reformation of the ancient Sanskrit tradition and doctrine-based poet and poetry. He has well weaved the conscious and subconscious mind of mankind in his poetry. It is really a significant contribution to the field of Modern Odia literature. Here, it should be told clearly that the treatment and the techniques of Guruprasad are quite different from him. Guruprasad has basically tried to instigate, involve and to stimulate the readers more and more though his indirect/oblique poetry techniques, or through his styles and irony and humours. But it is true that Rath has used more and more symbols and images than Mohanty in the crops of his poetry. This makes him absurd and obscure. Many of the critics say this for the uses of his personal symbols. Ramakant Rath is a fear to the general/ common readers of Modern poetry. Many of the readers take him as an abstruse, arcane and esoteric figure before reading his poetry. Similar Delphic and cryptic figures in Post-Independence Odia literature are Saubhagya Kumar Mishra, Deepak Mishra, Rajendra Kishore Panda, Pratibha Satapathy, Harihar Mishra and some other poets. "According to C.D. Thorpe, empathy is an attempt to explain imaginative experience in which there is an involuntary projection of ours into the object. In Ramakant this projection often suffers because of a possible conscious non-identification with the protagonist and, what would appear, the almost deliberate concealment of emotion in many of his poems. The symbols and images are sometimes so rapidly alerted and agglomerated that they break down the communication between the reader and the poet." (Mahapatra: 1997, 733) Many other poets have made their significant efforts in this period other than these poets like Sitakanta Mahapatra, Deepak Mishra, Rabindra Nath Singh, Haarihar Mishra, J.P. Das, Haraprasad Das, Pratibha Satapathy, Bramhotri Mohanty, Saubhagya Kumar Mishra, Benudhar Rout, Saurindra Barik, Binod Chandra Nayak, Ananta Patnaik, and many more. Basically, in this phase we notice a few significant things as the contemporary trend and tendency. Some of the poets followed the western patterns and some other the eastern one. Some used mostly the western myths and archetypes 
and some used the eastern. And the third type of poets used the both. Sitakant Mahapatra, in this regard, says, "They have fully exploited the capacity of the language for a fresh and powerful local idiom even while expressing concerns and themes that are universal. Their poetry has a quality of tentativeness and a sense of pathos that make an immediate connection with our troubled fate. Some of it has the quality of sophistication and complexity that is the hall-mark of great poetry and yet it has no respect for literary isms or emphasis on stylization or technical virtuosity. Like modern science it is often empirical in its approach to experience and has insisted on a fresh colloquial idiom that smells of the soil. Sometimes their themes are old archetypes or myths that are invested with new meaning and significance relevant to our times. It is a kind of poetry that is extremely rich and vibrant and has succeeded in breaking the communication barrier that had bedeviled so much of the earlier modern poetry. They insist that the voice of poetry should be both that of the Voyeur and of the man next door."'(1977, 734) When Guruprasad came dwindling in the sky of post-independence modern Odia poetry there were a few poets who were busy enough in experimentations in every regard as per their full capacity. All the poets in this phase were highly talented and widely accepted brilliant students and scholars. Many of them were IAS or OES or professors of universities and colleges etcetera. However, Eliot was the seed of all these attempts of this period. He has influenced too many people right from Guruprasad to Sitakant, Ramakant, Saubhagya, Harihar, Deepak, Pratibha and Rajendra as well.

\subsection{Eliot : In the Vessels of Modern Odia Poetry}

T.S. Eliot is the most influencing poet of entire twentieth century. Even today he is the ideal poet of many all over the world. By the way at that time during the post-independence era many poets started writing and reading the foreign poems and especially they started to understand the orientation of Both British and American literary (poetic) trends. This is the main reason for which we find the complexity in our lives. Like other literatures we see Odia literature influenced deeply by T.S. Eliot. Modern Odia literature, after the Independence and more particularly after the sixties, has very interestingly got various colours and numerous flavours like metaphysical, ironic, and mechanical and many other things in it. All these have been reflected in this period. In his final words Sitakant Mahapatra says,
"Modern Oriya literature particularly in poetry and fiction seems to be gradually coming round to this awareness of metaphysical style which is wedded to the lyric and the folk but is not rhetorical; which has concerns that are immediate and relevant and not superficial or extra-literary. It has been trying to connect 'everything with everything' a task it approaches with humility, tentativeness but a high degree of sincerity and devotion."(1977: 740)

Guruprasad is a prominent voice of that period. He is an exceptional talent who has really followed the personal beliefs or the doctrines of T.S. Eliot regarding poetry and became successful too. His long poem Kaalapurusha is not only his master piece but also it is the sole cause of his popularity and all those success. It is simply an attempt to translate The Waste Land but it came out as a piece of 'Trans-creation'. Further it became clear that it is of his credit only. Hence, if one says that Kaalapurusha is the copy, or mirror image or the clone of The Waste Land or if any such statement is given, it will be unfair and literally injustice to Guruprasad's talent and his natural efforts. Because it is not at all easy to dilute and mix the culture, economic condition, political condition, social status etcetera of a society or of a state into a text of another state, another nation or another culture. One must think of the distance and differences between the time and space and other things between The Waste Land and Kaalapurusha. Kaalapurusha was published in the Prajna in 1960. During this time there were two other new voices: Ramakant and Sitakant. These two had started their career as experimental writers. One was experimenting with myth and style. And another was experimenting with the symbols and imagery etcetera. Both had excellent level of anchor to language. They followed the western poets like Eliot, Auden, Tennyson, Yeats, Pound and Larkin, Neruda etcetera. Death and the complicated modern life was the central theme of these poets. Guruprasad was writing on these themes too. But the approaches of these poets were too different from Guruprasad. Guruprasad was more over a little more satiric and ironic than other contemporary writers. J.M. Mohanty discusses this in his essay "T. S. Eliot and Modern Oriya Poetry: A study in Assessment""Kalapurusha was published in 1960 and in the sixties Oriya poetry saw the emergence of two major poets, Ramakant Rath and Sitakant Mohapatra. Both were well-versed in English and western literature, 
and the former particularly was a student of English literature. Both Ramakant and Sitakant, like Guruprasad earlier, were motivated by the complicated problems of modern living and their poetry has been a record of tension and paradoxes that continually a modern man faces in his search for identity and sensibility. Their poetry, I general, has moved through many channels subsequently- in ways, that are away from any substantial influence or influences from the West. That is also the case with Guruprasad's later poetry which has moved away from his earlier kinship with Eliot. But both Ramakant and Sitakant, in their early phase, particularly in the sixties, showed affable links with Eliot in form, spirit and attitude, the particular examples being Ramakant's long poem Baghasikar (The Tiger Hunt), and Sitakant's long poems, including Mati O Manisha (The Earth and the Man) collected $\mathrm{n}$ the volume Astapadi (Eight Steps)." (2003: 203) Ramakanta Rath is an outstanding poet of Odia literature. Though at that time he was beginning his innings with some experiments still his very first attempt 'Ketedinara' was somehow successful and after that he got a distinctive place for his small poetry collection 'Anek Kothari' (A Number of Chambers). He got the prestigious Odisha Sahitya Akademi award very soon for his third poetry collection Sandigdha Mrugayaa. This is one of the powerful collections of Rath. J.M. Mohanty says-

"Baghasikar is only metaphorically a tiger hunt. It is a hunt for words, words that create and uncreate, give life and take away life, and with whom, spread out in multiple facets of existence, the poet wages a continuous tussle to establish himself, and his own identity, in the face of waste and decay.'(2003: 203)

The poem itself is a mysterious and very interesting one. Perhaps this is the best attempt of Rath till that time among all his works. The small sonnet 'Lantern' is also that much powerful and influential. From the very first quatrain to the couplet it is very famous and memorable. We can simply test the inner matrix in it. The Baagha Shikaar poem provides three complimentary situations. They are firstly, the unknown and a stranger forest. The second one is the situation of human being in the lap of myths and folklores. The third one is the familiar so called modern and social life of mankind in clubs and pubs and picnics and such other things. Here we see a better scene of post-independence life of mankind in Odisha. We can also taste and smell the post War-II human conditions from it. By the way a better understanding is there in this poem about the hopes, dreams and the hopelessness. Hope, desire to fulfill the wishes and its non-fulfillment are the either sides of this poetry. Hence, tiger is a symbol here. Its function is like time, the destroyer. The poem begins with a declaration about words that devour us, just like a tiger devouring its victims:

"Words at the first encounter

Words bloom at the yellow revival of forgotten love

Words sizzle at the heat of fear-

They are born and created on their own

They float in a nice, murmuring river

Like a light ship against the stream,

And then they devour us like tigers.

And who are we? -

The tiger's victim is a part of the tiger." (2003: 203-204)

(Translated by J.M. Mohanty)

'Baagha Shikaar' is a beautiful poem with full of symbols and images. It speaks about the existence of modern man. Loneliness, dryness, sterility, death and mental sickness are the central themes of this phase and particularly of this poem. It is his longest poem. "[...] the theme relates to the protagonist's life through suffering and his futile desire to renew himself in a situation of new power and new strength." (Mohanty: 2006, 523) It is a poem of poststructural concept. Devastation and recreation are the two sides of this poem. Again, both the processes; end and begin, destruction and creation are here in this poem's mind and heart. The light is a part of sheer darkness when the sun sets. But it ends with hesitation and uncertainty, and with a feeling that as if the victimization is not possible at all:
"Because of my light pieces of eyes all scattered, alas,
I cannot see him though I have waited all my life;
The tiger also cannot see me
As I sleep in a crowded hospital
Alone, helpless, in a grey summer,
And I wait to get into that body, O women,
Which I have lost in the jungles along with yours." (204)

(Translated by J.M. Mohanty)

Similarly, the taste of Rath could be better understood from one of his best poems 'Saagunaa' (Vulture). The 
poem could be compared with the poem 'Sailing to Byzantium' by W.B. Yeats. The theme of both the poems is one and that is the matter of the 'dying generation'. Similarly, we can see the motifs of another significant poet of this period Sitakant Mohapatra from some examples. Sitakant's poem 'Maati O Manisha' deals with isolation, helplessness, darkness of spirit and obsession with death-mental aspects seen in the context of Vasudeb's imprisonment in the prison of Kansa. But as Vasudev waits in hope, however remote and frail that may be, of the birth of his eighth child, who may (or who knows, may not), be able to dispel his suffering (both physical and mental), so also the protagonist attempts to move away from his 'darkness' and 'emptiness' towards some 'plenty' through his hopes of a contact with soil and fruition. Thus the beginning encircling darkness,

"Darkness inside

Dark, dark

Threads of darkness intertwined interlocking Supporting on stone, iron-

And doors and doors

And iron bolts innumerable

And thick darkness,

Layers, and layers..."

Moves to fear of death,

"Who are you?

Who? Who do you call me?

Where? why?

I am afraid

The pale moon outside

And the last hour of the night."

The specialty of Mohapatra is the use of Myth. Myths articulate the modernity. This is the unique style of Mohapatra. He has always done all his deals with modernity by virtue of myths. Various myths like folk myths, myths from legends, literatures, Puraanas, Mahapuraanas, Kaavyas and Mahakaavyas. We can encounter it from the example from the long poem cited earlier. There finally the dream of that eight child comes like this:

The dark fortnight of Bhadrav

And the sky and the earth

Darkness, darkness

And the middle of the night,

The eight day,

The confluence of Rohini and Vrusha,

And the rain of flowers from the sky

And the noise of drums,
And the horizons bright, glowing

And the divine woman dancing all around, And to a dream of soil and fruition

The invitation of the harvest

The impassioned call of a full-blooded earth

And the dream of the eighth child.

Beyond iron and stone

Beyond bolts and walls." (2003: 205)

(Translated by J.K. Mohanty)

Professor Mohanty has rightly told that, "Eliot's influence provided a break-through in Oriya poetry, giving rise to a rich harvest, and acted as a fertilizing agent for major modern Oriya poets. Oriya poetry today is established in its own power and vigour. But an acknowledgement of the share of a fine poet whose poetry spurred the movement towards newness and eventual rich growth, is both due and beneficial." (2003: 205) The master pieces of Mohapatra are: Dipti o Diyuti, (Lustre and Luminance, 1963), Ashtapadee (Eight Steps, 1967) Shabdara Aakaasha (The Sky of Words, 1971), Samudra (The Sea, 1977) Chitranadee (The Pictorial River, 1979), Aara Drushya (The Other Scene, 1981), Samayara Shesha Naama (The last name of Time, 1984), Kaahaaku Puchhibaa Kuha (Say, Whom to Ask, 1987), Chadheire Tu ki Jaanu? (Oh Bird, What do You know? 1990), Pheri Aasibaara Bela (The Time of Return, 1991), Barshaa Sakaala (The Rainy Morning), Padachinha (The Footprint), Mrutiyu ra Aseema Dharjya (The Infinite Patience of Death), Kapatapaashaa (The False Dice, 2000), Pradkshina (To Rake Around, 2002) etcetera. These show the post-independence and the trends after 1960-70 too. Similarly, with the same flow of time we can take the names of a few poets like Gopal Chandra Mishra, Raghynath Dhala Samanta (b.1924-d.1972), Chakradhar Rout (b.1925), Durga Charan Kuanr (b.1925.-d.2009), Bhanuji Rao (b. 1926-d.-2001), Shyama Sundar Das (b.1926), Chintamani Behera (b.1928-d.2005), Banamali Senapati (b.1927-d.2005), Jayanta Mahapatra (b.1928), Durga Madhab Mishra(b.1929-d.1997), Durga Charan Parida (b.1931), Krushna Charan Behera (b.1931-d.2017), Umashankar Panda (b.1931), Rabi Singh (b.1932) and few other poets as Guruprasad's contemporary poets in the post-independence phase. Still, among these poets and even among the previous poets he his quite conspicuous, different and powerful too. 


\section{Influence of Eliot on Guruprasad}

Guruprasad Mohanty is truly a modern poet. His dealings, his practice and specialties- all are reserved by himself which are very close to modernism as well as post-modernism. The biggest thing ever, above all these things is the copyright of his styles is reserved by himself. Many critics say that if there won't be any Eliot we could not see Guruprasad. It sounds quite unnatural. Because Guruprasad was there with his own colour, own flavour and own style which was quite traditional and quite original before entering into the domain and range of T.S. Eliot. Now we can catch the lines of J.M. Mohanty in this regard. "The Waste Land was published in 1922, and Little Gidding in 1942, and in between Eliot's most important poems were published. But by 1939, when the Second World War began, T.S. Eliot's had been the most important name to conjure with, and in the world poetry-circle he was much admired and respected. In fact, Nobel Award to him in 1948 was only a belated recognition and only put a stamp on that which had become an accepted fact. The point is, during the intervening years between the two World Wars, Eliot's rise to prominence constituted almost a unique source of power and inspiration to sensitive poets all over the world, and particularly in those places where English literature was studied or English language was spoken. In other words, in thirties and forties, Eliot's poetry became a potent source of influence on alert, sensitive India poets, and his criticism and critical views provided a strong element of nourishment to advance critical intelligence. The times were uncertain, the changes were rapid, and in those years immediately before Independence as the Indian sensibility was trying to adjust itself was trying to adjust itself to the new, complex predicament of living, it found a kinship with Eliot, particularly with the poet's vision and understanding of life. Tagore was aware of Eliot, and it is pointed out that Tagore's later poetry had some affinity with that of Eliot. But in Bengal it was the other group, the poets younger to Tagore, such as Sudhindra Dutta, Budhadeb Bose, Bisnu Dey and Samar Sen, who were closer to Eliot in spirit and form, and in a way put forth their reactions to contemporary life as significantly as Eliot had done in his poetry. But it was not so in all Indian languages. It was surely not the case in Oriya poetry in the thirties and forties."(2003:194) Up to Samudra Snaana we see Guruprasad as a follower of Eliot. What after that? We will surely do injustice in measuring the talent of Guruprasad if we remark like this and see only one corner of his poetic personality.
At the end of any work Mohanty has given such a finish that it is quite hard to know whether he has imitated anybody or not. Because he puts the grinded originals matters of the land, air and water in such a manner with marble-cut finishing touch that those fit beautifully into each and every hole and joint of the work with ultimate perfection. This brings his originality and creativity out with a layer of shining wax.

J.M. Mohanty has given some contemporary personal experiences which are really beneath this literary practice. Really "[...] the greater exponent of the new mode in Oriya poetry was Guruprasad Mohanty. Unlike Routray, he was a student and teacher of English literature and was well-versed in contemporary English poetry, including poetry of Eliot. In this he was ably inspired and supported by Professor Bidhubhusan Das who incidentally in the late forties and early fifties, inspired generations of young students in contemporary British authors such as Eliot, Lawrence, Leavis etc. Professor Das's influence was seminal, and largely shaped Guruprasad's creative power at an important initial stage. Guruprasad was writing casual poems on love and sentence in a general romantic mode with a tinge of parody at the expense of contemporary romantic writers. This changed, and some of his poems published in the early fifties in the journals brought shock, surprise and a great deal of excitement among the readers, both of older and younger generations. The feeling was it was something new, the type of which Oriya poetry had never seen before, and as if overnight devices such as wit, irony, paradox and ambiguity became popular with young writers, and a general skeptical attitude towards the so called important things of life, including love, ambition, youth became current. In short, Oriya poetry in the early fifties suddenly came of age, thanks to Guruprasad and Eliot.”(2003:198) Surendra Kumar Maharana has rightly told- "His language is full of variety, potency and self-tuned. The blending of newness and emotion in his language sparks the liking sect of a reader's mind and heart. Though his 'Kaalapurusha has assimilated many aspects and many themes of T.S. Eliot's The Waste Land many elementary entities are there still conspicuous." (502) An early poem was there entitled Gobar Ganesh (The Impotent). This poem was fully influenced by T.S. Eliot's 'Love Song of J. Alfred Prufrock' and 'Gerontion'. The theme of the three poems relates to impotency in love making along with an awareness of 
growing age. How time makes us old, weaker and faded- this philosophy has been thrown here in this Odia poem Gobar Ganesh. "Thus, the conclusion is, as in 'Gerontion', 'thoughts of a dry brain of a dry season". The poem begins with a sense of loss- a sense that is almost everywhere, in the body, in the brain, in the consciousness, as well as in the 'broken walls of sand', 'on the grey sea beach', in the 'vanishing shadow' in the 'lonely street corner', and the 'trailing cuckoo's songs' in the 'storm of spring'. This is most evident in the protagonist, particularly in his desire to be effective sexually. But he is also aware of the passing time, of leaves falling off continually and vanishing $n$ the wind ("As leaves fall off today in the evening/ As evening tiptoes like a sly lover from this lonely street/ I sit beside the window/ Squeezing things in my breast-pocket/ Jasmine garlands the champak blossoms/ Her saree and her blouse/ And her round breasts and dark eyes/ And my body, my mind, my soul and my masculinity/ Squeezed in a handkerchief/... Leaves continue to fall/And dust floats away from the lonely street.") the tension arises from contradictory situations-one at the level of desires, and the allied pretensions, poses and preaching, and the other at the level of reality-reality of passing time and growing age. Any attempt to resolve the tension only leads to more tension, and to a condition of pity and helplessness, where the lady laughs at the pretensions of the protagonist-" If she laughs/ Only laughs/Blending her body as gracefully as a doe/ If she says/ It's wrong, all wrong/ You are an ass, a fool, a clown/ It's all your fancy of pastforty/ If she ripples like a stream on her bed/ I swallow my spit/ My throat becomes dry". At the end the protagonist accepts the inevitable- of time passing, of people growing old, of youth going to die, and all his musing are his helpless groping, unsatisfied desires, dry thoughts in a dry brain- "Startled I see/ How leaves fall/ How the trees stand like dark stumps/And time squints when waves swallow waves/ and the street-corner snarls like the crack in her lips". (2003:198-99) After independence we face several sociological problems within our society and within ourselves. J.M. Mohanty has said in his survey of Modern Odia literature that- "Between Independence and 1975, a period of about thirty years, Oriya literature went through a sea-change, with new dimensions being added since. Whereas modern Oriya literature before Independence more or less followed well-defined and familiar lines such as sensitiveness to nature and involvement in such emotions as love and mysticism, or acquiescence to nationalistic and patriotic feelings, or compassionate camaraderie with the downtrodden and the poor, or even in the expression of implicit horror at the shift of culture from rural to urban surroundings, post-independence literature exhibited a wide variety of emotions, sensibilities, attitudes and approaches as well as multifaceted themes related to the social, political, and cultural atmosphere on the one hand, and psychological problems of sentience and existence on the other." (1992:309-310) There was a challenge in that time. This is not at all an easy phase of literature. Changes were too much and awareness were there in that rate. Hence a kind of 'resilience for adaptation' is visible in this literature and of course in the life of this time. In that age the man started living in a world of industrialization, nuclear holocaust who was living in a green village environment. The phase was the age of demolition, a kind of conflagration. The changes were rigorous and were numerical as well as in terms of attitude. All these things have been reflected in the Post-independence literature and also in Guruprasad's poetry which is quite obvious too. J.M. Mohanty, in his essay "T.S. Eliot and Modern Oriya Poetry: A study in Assessment", says-

"A related poem was Priyabandhabi (Dearest Lady), also published at the same time. The theme is a desire for love and the protagonist's inability to be effective about it. The poem proceeds at two levels-one, the presence of loneliness and despair due to growing age through which the protagonist now lives, and the other of a past of a meaningful companionship which comes only through recollection. The emptiness of the present contrasted with the feelings of past fulfillment and at the end they are together resolved in an ironical inevitability of passing time and the related process of decay. Thus a waiting for the lady is almost like an exercise in futility"Come today, only once, even though everything is lifeless/These trees, these creepers, this forest, and the waves and sands/When the moon in the sky is tired and meaningless/ I wait for you/Full of questions and in doubts", and the final vision is one of complete annihilation when the protagonist, many years hence and in a wasteful time, merges himself with the lady in a condition of complete waste and decay."(199) 
Post-independence Odia literature is problem literature as its principal deal is with various problems of mankind and the society of the time. Now the national, local or the state literature merged in to the wide spectrum of cosmopolitan literature. A kind of Glocal (Global + Local) literature took a birth. Literatures of this period are started from the local bases and ended in the foreign sky. We can better name it as the cosmopolitan sky. This was the attitude of the post-colonial literature as a whole. Modern writers and their writings in almost all the forms were of local manifestations with cosmopolitan attitudes and inclination. Further we see a kind of detour in this approach. We call this detour 'Post-Modernism' which was/were already there within us. Hence, it is a kind of realization; a crystal-clear consciousness about the self and the inner self of individual, society, culture, tradition and the society separately and together.

\section{Conclusion}

Overall it could be concluded herewith that Guruprasad is a versatile poet who has exercised his mind and heart in a few selected areas of poetry blended in philosophy and fortunately he has got immense success in it. From the day of Radhanath Ray experimentations can be seen in literature in various terms and types. The Satyavaadi School has focused in a single point thereafter but has brought few new things to the domain of Modern Odia literature. Similarly, the Sabujities have performed well during the vacuum phase of Odia literature. We can never forget the Marxist footprints on the sands of Odia literature too. But the way poetry and the entire genre of literature have been changed after independence is really remarkable and shocking too. The folk character, the nature, attitude and sociopolitical and cultural perspectives changed totally. Guruprasad is the significant flag holder of this change. He has made his experiment in a few fields and has got success in those. The main thing is that he has made his own tune, and own genre to which many of the poets of the future generation have adopted, accepted and widely utilized. Some have done further experiments on the same tune and style and genre. Long poem tradition, successful use of myth and image with the theme of existentialism and other isms starts successfully from Guruprasad. Even Routray has not got that much of success in his entire experiments how and what Mohanty has got in his few attempts. The long poem 'Kaalapurusha' and some significant poems like 'Gobara Ganesha', 'Harekrushna Das-1,2,3 \& 4' and the incomplete long poem 'Jaatra' are the evidence of the same. However, it is quite clear from the above things that though many have followed T.S. Eliot in their poetic passages, though many have followed his poetic styles in their poetry still it is transparent from the comparative critical analyses of the poetry of the contemporary poets that Guruprasad is too much eligible to create his own tune and own music with own genre. He is a real hero, a real trend setter and of course a real 'Guru' and real 'Prasad' in the so called Post-independence Odia poetry.

\section{Work Cited:}

1) Acharya, B.C., Odia Saahityara Sanksipta Parichaya. Cuttack: Grantha Mandir, 2001.

2) Das, Cittaranjan, A Glimpse into Oriya Literature. Bhubaneswar: Orissa Sahitya Akademi, 1982.

3) Das, Dasarathi, Aadhunika Kaabya Jignyaasa: Chitrakalpa. Cuttack: Friends Publishers, 2015.

4) Mahapatra, Sitakant, "Connecting Everything to Everything' Landmarks in PostIndependence Oriya Literature” In: Sidelights on History and Culture of Orissa. ed. Manmath Nath Das, Cuttack: Vidyapuri, 1977.

5) Maharana, Surendra Kumar, Odia Saahityara Itihaasa. Cuttack: Orissa Book Store, 2015.

6) Mansinha, Mayadhar, A History of Oriya Literature. New Delhi: Sahitya Akademi, 2012.

7) Mohanty, J.M. "Modern Oriya Literature". In: Modern Indian Literature: An Anthology (Vol.-I) ed. K.M. George, New Delhi: Sahitya Akademi, 1992.

8) Mohanty, J.M., "T.S. Eliot and Modern Oriya Poetry: A study in Assessment”. Tradition and Creativity Essays on Oriya Literature. Bhubaneswar: Subarnarekha. 2003.

9) Mohanty, Jatindra Mohan, History of Oriya Literature. Bhubaneswar: Vidya, 2006.

10) Nayak, Santosh Kumar, "The Text and Context of Mayadhar Mansingha's Poetry" KAAV International Journal of English Literature and Linguistics- Vol. 4, Issue-1/A6, Jan- 2017, pp.23-40, ISSN- 2349-4921. 
International Journal of Trend in Scientific Research and Development (IJTSRD) ISSN: 2456-6470

11) Parida, Nilamani, Saraswati Ramakanta. Kendrapada: Basundhara, 2013.

12) Rath, Prafulla Kumar, Odiaa Saahityare Prateeka O Prateekabaada. Puri: Manjushree Rath. 1996.
13) Satapathy, Nityananda, "Development of Modern Oriya Literature (1803-1977)” In: Sidelights on History and Culture of Orissa. ed. Manmath Nath Das, Cuttack: Vidyapuri, 1977.

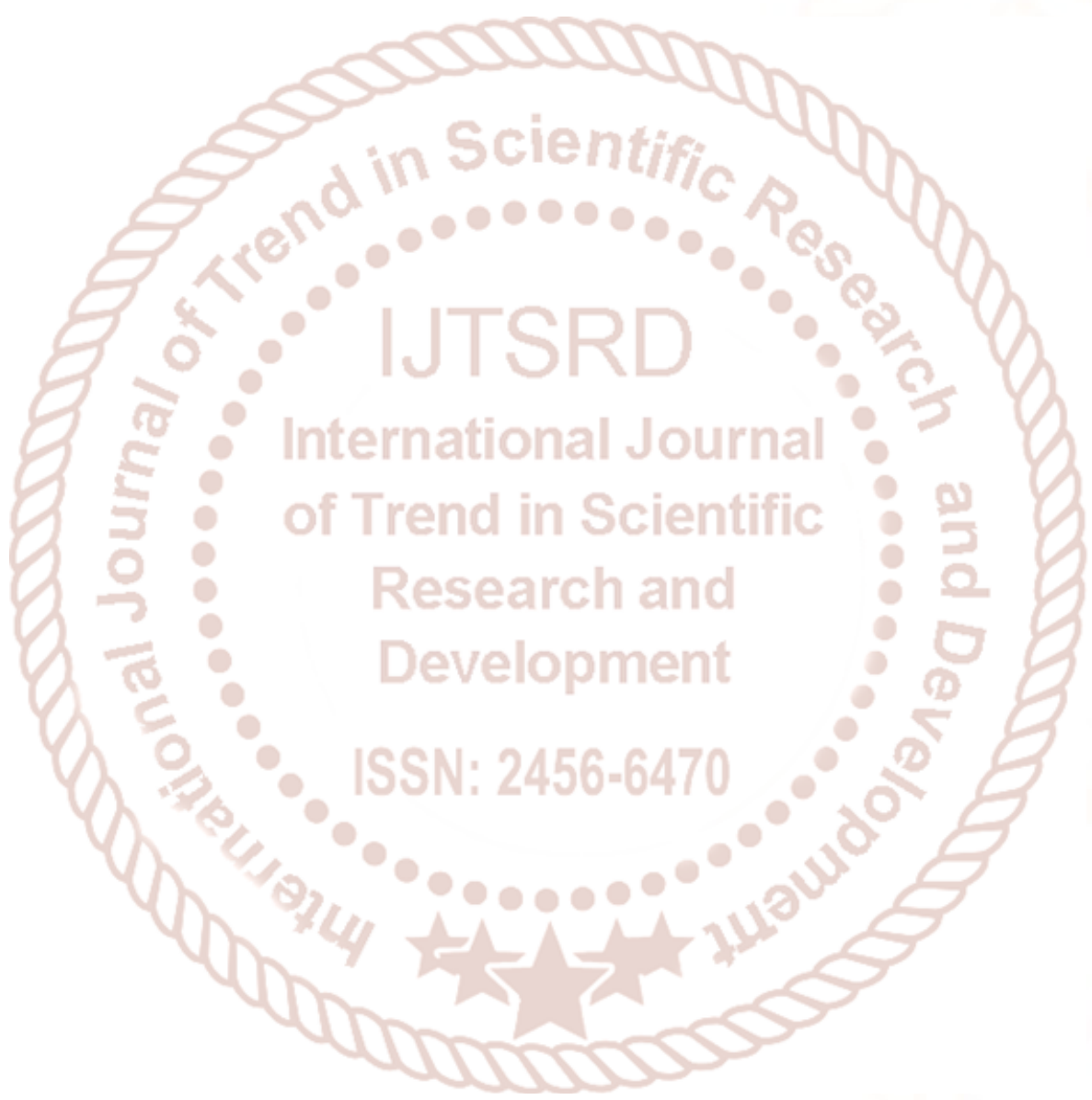

